\title{
Receptors of the Glial Cell Line-Derived Neurotrophic Factor Family of Neurotrophic Factors Signal Cell Survival through the Phosphatidylinositol 3-Kinase Pathway in Spinal Cord Motoneurons
}

\author{
Rosa M. Soler, Xavier Dolcet, Mario Encinas, Joaquim Egea, Jose R. Bayascas, and Joan X. Comella \\ Grup de Neurobiologia Molecular, Departament de Ciències Mèdiques Bàsiques, Facultat de Medicina, Universitat de \\ Lleida, 25198 Lleida, Catalonia, Spain
}

\begin{abstract}
The members of the glial cell line-derived neurotrophic factor (GDNF) family of neurotrophic factors (GDNF, neurturin, persephin, and artemin) are able to promote in vivo and in vitro survival of different neuronal populations, including spinal cord motoneurons. These factors signal via multicomponent receptors that consist of the Ret receptor tyrosine kinase plus a member of the GDNF family receptor $\alpha$ (GRF $\alpha$ ) family of glycosylphosphatidylinositol-linked coreceptors. Activation of the receptor induces Ret phosphorylation that leads the survival-promoting effects. Ret phosphorylation causes the activation of several intracellular pathways, but the biological effects caused by the activation of each of these pathways are still unknown. In the present work, we describe the ability of the GDNF family members to promote chicken motoneuron survival in culture. We show the presence of Ret and GFR $\alpha-1$, GFR $\alpha-2$, and GFR $\alpha-4$ in chicken motoneurons using in situ
\end{abstract}

hybridization and reverse transcription-PCR techniques. By Western blot analysis and kinase assays, we demonstrate the ability of these factors to induce the phosphatidylinositol 3 kinase ( $\mathrm{Pl}$ 3-kinase) and the extracellular regulated kinase (ERK)-mitogen-activated protein (MAP) kinase pathways activation. To characterize the involvement of these pathways in the survival effect, we used the PI 3-kinase inhibitor LY 294002 and the MAP kinase and ERK kinase (MEK) inhibitor PD 98059. We demonstrate that LY 294002, but not PD 98059, prevents GDNF-, neurturin-, and persephin-induced motoneuron survival, suggesting that PI 3-kinase intracellular pathway is responsible in mediating the neurotrophic effect.

Key words: GDNF; persephin; neurturin; artemin; motoneuron; neurotrophic factor; GFR $\alpha$ receptors; chicken; intracellular signaling pathway
Glial cell line-derived neurotrophic factor (GDNF), neurturin (NTN), persephin (PSP), and artemin (ART) are the members of a new family of neurotrophic factors distantly related to the members of the TGF $\beta$ family (Lin et al., 1993; Buj-Bello et al., 1995; Trupp et al., 1995; Kotzbauer et al., 1996; Maxwell et al., 1996; Klein et al., 1997; Baloh et al., 1998; Horger et al., 1998; Milbrandt et al., 1998). All of them can support the survival of a wide variety of neuronal populations in both the peripheral nervous system and CNS, including motoneurons (MTN) (Henderson et al., 1994; Oppenheim et al., 1995; Klein et al., 1997; Milbrandt et al., 1998). GDNF family members signal via multicomponent receptors that consist of the Ret receptor tyrosine kinase plus a glycosylphosphatidylinositol (GPI)-linked corecep-

\footnotetext{
Received April 15, 1999; revised July 19, 1999; accepted Aug. 11, 1999.

This work was funded by Spanish Govern Comisión Interministerial de Ciencia y Tecnologia through the Plan Nacional de Salud y Farmacia (Contract 97-0094), Telemarató de TV3 (edició 1997: Malalties Degeneratives Hereditàries), European Union Biotech Program (Contract BIO4-CT96-0433), and Ajuntament de Lleida. We thank Isu Sanchez for her technical support. We also thank Eugene M. Johnson and Jeff Milbrandt (Washington University, St. Louis, MO) for supplying the neurotrophic factors and Malú G. Tansey (Washington University, St. Louis, MO) for her scientific comments and help. GFR $\alpha$ plasmids used for the in situ hybridization were a generous gift of Alun M. Davies (University of St. Andrews, Fife, Scotland). M.E. and J.E. are predoctoral fellows funded by Generalitat de Catalunya, and X.D. is a predoctoral fellow funded by the Spanish Government. J.R.B. is a postdoctoral fellow funded by European Union Biotech Contract BIO4-CT96-0433.

Drs. Soler and Dolcet contributed equally this work.

Correspondence should be addressed to Joan X. Comella, Grup de Neurobiologia Molecular, Departament de Ciències Mèdiques Bàsiques, Universitat de Lleida, Rovira Roure, 44, 25198 Lleida, Spain.

Copyright (C) 1999 Society for Neuroscience $\quad 0270-6474 / 99 / 199160-10 \$ 05.00 / 0$
}

tor named GDNF family receptor $\alpha(\mathrm{GFR} \alpha)$, which gives binding specificity. GDNF binds preferentially to GFR $\alpha-1$, NTN shows binding preference to $\operatorname{GFR} \alpha-2$, PSP to GFR $\alpha-4$, and ART to GFR $\alpha$-3 (Buj-Bello et al., 1997; Klein et al., 1997; Baloh et al., 1998; Enokido et al., 1998). Recently, deficient mice for the GDNF family members GDNF (Moore et al., 1996; Pichel et al., 1996; Sanchez et al., 1996) and NTN (Heuckeroth et al., 1999), for their cognate receptors GFR $\alpha$-1 (Cacalano et al., 1998; Enomoto et al., 1998) and GFR $\alpha-2$ (Rossi et al., 1999) or for Ret (Schuchardt et al., 1994), have been generated. Analysis of the trigeminal motor nucleus and the spinal cord show moderate loss of MTNs in GDNF (Moore et al., 1996; Sanchez et al., 1996) and GFR $\alpha-1$ (Cacalano et al., 1998) mutants. However, the facial nucleus does not show significant variation in the number of MTNs in the same animals.

Binding of GDNF family of neurotrophic factors to Ret and GFR $\alpha$ family members induce Ret phosphorylation (Durbec et al., 1996; Jing et al., 1996; Treanor et al., 1996; Trupp et al., 1996). After phosphorylation, Ret induces the activation of several intracellular pathways, among which the extracellular regulated kinase (ERK)-mitogen-activated protein (MAP) kinase and the phosphatidylinositol 3 kinase (PI 3-kinase) are of particular interest (Kotzbauer et al., 1996; Creedon et al., 1997). PI 3-kinase has been implicated in the survival-promoting mechanisms (Yao and Cooper, 1995; Dudek et al., 1997; Miller et al., 1997; Crowder and Freeman, 1998; Dolcet et al., 1999) and ERK-MAP kinase seems to be involved in differentiation processes (Qiu and Green, 1992; Cowley et al., 1994; Fukuda et al., 1995; Pang et al., 1995). To understand the mechanisms implicated in the GDNF family- 
mediated MTN survival and the intracellular pathways involved in this process, we have investigated the ability of GDNF, NTN, and PSP to activate PI 3-kinase and ERK-MAP kinase pathways. We provide evidence showing that all these neurotrophic factors are able to activate both pathways in our culture system, and the PI 3-kinase pathway has an important role on MTN survival, whereas the Ras/MAP kinase does not have a relevant contribution in this process.

\section{MATERIALS AND METHODS}

MTN isolation, survival evaluation, and cell death characterization. MTNs were purified from embryonic day 5.5 (E5.5) chick embryos according to Comella et al. (1994) with minor modifications described by Dolcet et al. (1999). Survival evaluation was performed as described by Soler et al. (1998).

Neurotrophic factors were obtained from E. M. Johnson and J. Milbrandt (Washington University, St. Louis, MO) and were prepared as described by Creedon et al. (1997).

To evaluate the cell death process, cultures were stained with the Hoechst 33258 dye (Sigma, Madrid, Spain). MTNs $\left(2 \times 10^{5}\right)$ were grown in $35 \mathrm{~mm}$ culture dishes for $48 \mathrm{hr}$ in the presence of muscle extract (MEX), and then cells were washed and grown for an additional $15 \mathrm{hr}$ with culture medium containing different supplements or drugs. At that time, medium was removed, and cells were washed once with PBS and fixed with 4\% (w/v) paraformaldehyde (Fluka, Buchs, Switzerland) in PBS for $30 \mathrm{~min}$. Neurons were stained for $30 \mathrm{~min}$ with $0.5 \mu \mathrm{g} / \mathrm{ml}$ Hoechst 33258 and were mounted with glass coverslips using Fluoprep (Biomerieux, Marcy-l'Etoile, France). Stained cells were observed and counted with a vertical microscope equipped with epifluorescence and UV filters. Results are expressed as the percentage of apoptotic cells with respect to the total cell number counted in each condition (1000 cells) and show the mean \pm SEM of the percentages for three independent experiments. Where applicable, statistical analysis was performed with the Student's $t$ test.

To assess the enzymatic activity of caspases in dying MTNs, cultures were grown in the presence of MEX during $48 \mathrm{hr}$. After this period of time, cells were washed and treated in the indicated culture media. At the adequate time, cells were rinsed with ice-cold PBS and lysed in a buffer containing $100 \mathrm{~mm}$ HEPES, pH 7.4, 5 mM DTT, 5 mM EGTA, 0.04\% NP-40, and $20 \%$ glycerol. Extracts were then centrifuged at $5000 \times g$ for $10 \mathrm{~min}$, and protein concentrations were determined by Bradford assay (Bradford, 1976). Eight micrograms of cell extracts were diluted in $50 \mu \mathrm{l}$ of reaction buffer (100 mM HEPES, pH 7.4, 5 mM DTT, $5 \mathrm{~mm}$ EGTA, $0.04 \%$ NP-40, and 20\% glycerol) and incubated with $100 \mu \mathrm{M}$ fluorescent substrate Z-DEVD-AFC (Enzyme System Products, Livermore, CA) at $37^{\circ} \mathrm{C}$ for $1 \mathrm{hr}$. The fluorescent signals were determined with a spectrofluorometer (Bio-Tek Instruments, Winooski, Vermont) at an excitation wavelength of $360 \mathrm{~nm}$ and an emission wavelength of $530 \mathrm{~nm}$. Protease activity was expressed as the amount of cleaved substrate per microgram of protein per minute ( $\mathrm{pmol}$ of $\mathrm{AFC} \cdot \mathrm{min}^{-1} \cdot \mu \mathrm{g}$ of protein).

In situ hybridization. Probes were generated by transcribing linearized plasmids containing the cDNA for the desired chicken gene, obtained from Alun M. Davies (University of St. Andrews, Fife, Scotland). The GFR $\alpha$-1-, GFR $\alpha$-2-, and GFR $\alpha$-3-containing plasmids were linearized with PstI, SphI, and SacII, respectively, and transcribed with T7, T3, and SP6 RNA polymerases to generate 686,626 , and 800 bp antisense probes, respectively. The Ret probe was synthesized from total RNAs of MTNs using specific primers corresponding to positions 983-1007 for the forward direction and 2035-2059 for the reverse direction of the published sequence (Robertson and Mason, 1995). The amplified fragment gives a product of 1076 bp that was subcloned in pBluescript SK (Stratagene, La Jolla, CA). Antisense probes were obtained by digesting the plasmid with Bam HI and transcribed with T7.

For in situ hybridization, chicken embryos were immersion-fixed for $12-16 \mathrm{hr}$ at $4^{\circ} \mathrm{C}$ in $4 \%$ paraformaldehyde in $0.1 \mathrm{M}$ sodium phosphate buffer, pH7.4, cryoprotected overnight in $30 \%$ sucrose, embedded in Tissue-Tek(Miles, Inc, Elkhart, IN), and frozen. Fourteen micrometers of transversal sections were cut using a cryostat, collected onto 3 -aminopropyltriethoxysilane-coated slides, and stored at $-80^{\circ}$ until they were used. Sections were air dried for 2-3 hr before use, treated during 30 min with $1 \%$ Triton X-100 in PBS, post-fixed with $4 \%$ paraformaldehyde for $10 \mathrm{~min}$, and acetylated in $0.25 \%$ acetic anhydride and $0.1 \mathrm{M}$ triethanolamine $\mathrm{HCl}$ for $10 \mathrm{~min}$. Sections were prehybridized $1 \mathrm{hr}$ at room temperature in a solution containing $50 \%$ formamide, $5 \times \mathrm{SSC}, 2 \%$ blocking reagent (Boehringer Mannheim, Barcelona, Spain), $1 \mathrm{~mm}$ EDTA, $1 \mathrm{mg} / \mathrm{ml}$ tRNA, $0.5 \mathrm{mg} / \mathrm{ml} \mathrm{Herring} \mathrm{sperm} \mathrm{DNA,} 0.1 \%$ CHAPS, and $0.1 \%$ Tween 20 . Hybridization was performed in the same solution containing $500 \mathrm{ng} / \mathrm{ml}$ the respective denatured probe for $16-20 \mathrm{hr}$ at $60^{\circ} \mathrm{C}$ and subsequently washed three times for $15 \mathrm{~min}$ in $0.2 \times \mathrm{SSC}$ at the hybridization temperature. Sections were blocked with $10 \%$ fetal calf serum (Life Technologies, Barcelona, Spain) and $2 \mathrm{mg} / \mathrm{ml} \mathrm{BSA}$ in $0.1 \mathrm{M}$ Tris, $\mathrm{pH} 7.5$, and $0.150 \mathrm{M} \mathrm{NaCl} 1 \mathrm{hr}$ at room temperature. Digoxigeninlabeled nucleotides were detected with an alkaline phosphataseconjugated anti-digoxigenin antibody. The antibody was developed with 4-nitro blue tetrazolium chloride and 5-brom-4-chlor-indolyl-phosphate.

Reverse transcription-PCR. A semiquantitative reverse transcription (RT)-PCR assay was used to compare the expression levels for Ret, GFR $\alpha-1, \operatorname{GFR} \alpha-2$, and GFR $\alpha-4$ in E7.5 chicken spinal cord and $48 \mathrm{hr}$ cultured MTNs. One microgram of total RNA (Chomczynski and Sacchi, 1987) was digested with 2 U of DNase I RNase-free (Amersham Pharmacia Biotech, Uppsala, Sweden) and was reverse transcribed using 1 nmol of random hexamers (Boehringer Mannheim) and $200 \mathrm{U}$ of Moloney Murine Leukemia Virus Reverse Transcriptase (Promega, Madison, $\mathrm{WI}$ ) for $1 \mathrm{hr}$ at $37^{\circ} \mathrm{C}$. Ten nanograms of cDNA were used to perform a multiplex PCR amplification, with $200 \mathrm{~nm}$ each Ret, $\operatorname{GFR} \alpha-1, \operatorname{GFR} \alpha-2$, and GFR $\alpha-4$ set of primers and $20 \mathrm{~nm}$ each housekeeping L27 ribosomal protein as an internal control. Samples were subjected to 27-30 cycles of $94^{\circ} \mathrm{C}$ for $20 \mathrm{sec}\left(60^{\circ} \mathrm{C}\right.$ for Ret and $\mathrm{GFR} \alpha-4,50^{\circ} \mathrm{C}$ for $\mathrm{GFR} \alpha-1$, and $53^{\circ} \mathrm{C}$ for $\mathrm{GFR} \alpha-2$ ) and $72^{\circ} \mathrm{C}$ for $30 \mathrm{sec}$ on a Perkin-Elmer (Emeryville, CA) thermal cycler, with hot start at $94^{\circ} \mathrm{C}$. All products were analyzed on $3 \%$ ethidium bromide-stained gels. Care was taken to arrest the amplification in the linear phase that was determined in pilot experiments. To achieve this, the amount of product was plotted against number of cycles and amount of starting sample.

Primer sequences were as follows: Ret forward, TCGCTACCACAAGAATTCTCCAAAG; Ret reverse, GATGGGATATGACTGGGCTGGGCGC; GFR $\alpha-1$ forward, ACCTGAGAAGGAGGATGG; GFR $\alpha-1$ reverse, TGACATCCTTGATAATCT; GFR $\alpha$ - 2 forward, CCTTTGTGGATCAGAAGGC; GFR $\alpha-2$ reverse, AGCTTCAGCAGCACAATGG; GFR $\alpha-4$ forward, ACCATCGTTCCGGCCTGCTCC; GFR $\alpha-4$ reverse, GCATAACGCGACCTACAGACG; L27 forward, AGCTGTCATCGTGAAGAACAT; and L27 reverse, CTTGGCGATCTTCTTCTTGCC.

Primers for GFR $\alpha-1$ and GFR $\alpha$-2 were described previously by Thompson et al. (1998) and those for L27 by Allsopp et al. (1993). The amplified products for Ret, GFR $\alpha-1, \operatorname{GFR} \alpha-2, \operatorname{GFR} \alpha-4$, and L27 were $82,99,82,101$, and 128, respectively.

Immunoprecipitation, Western blot analysis, and kinase assays. Ret phosphorylation assay was performed as described by Creedon et al. (1997) with minor modifications. Briefly, $100 \mu \mathrm{g}$ of protein was immunoprecipitated with $1 \mu \mathrm{g}$ of 4G10 anti-phospho-tyrosine antibody (Upstate Biotechnology, Lake Placid, NY). Immunocomplexes were collected with a mixture of Protein A and Protein G (Sigma) and resolved by Western blot as described below. Before the immunoprecipitation, 10 $\mu \mathrm{g}$ of protein was removed and blotted to assess equal loading of the lanes.

For detection of the phosphorylated forms of MAP kinase and ERK kinase (MEK), ERK2, and Akt in total cell lysates, $10 \mu \mathrm{g}$ of total protein was resolved in SDS-polyacrylamide gels and transferred onto polyvinylidene difluoride Immobilon-P transfer membrane filters (Millipore, Bedford, MA) using an Amersham Pharmacia Biotech semidry TransBlot according to the manufacturer's instructions. The membranes were blotted with specific anti-phospho-MEK (anti-P-MEK), anti-phosphoERK (anti-P-ERK), and anti-phospho-Akt (anti-P-Akt), antibodies (New England Biolabs, Beverly, MA) following the instructions of the provider. To control the content of the specific protein per lane, membranes were stripped with $100 \mathrm{~mm} \beta$-mercaptoethanol and $2 \%$ SDS in $62.5 \mathrm{~mm}$ Tris- $\mathrm{HCl}$, pH 6.8 , for $30 \mathrm{~min}$ at $70^{\circ} \mathrm{C}$ and reprobed with a rabbit anti-pan-MEK antibody (New England Biolabs), a mouse monoclonal anti-pan-ERK antibody (Transduction Laboratories, Lexington, K Y), or a goat anti-pan-Akt antibody (Santa Cruz Biotechnology, Santa Cruz, CA) as described by the providers. Ret was detected with a similar protocol, but antibodies specific for this protein were used (Santa Cruz Biotechnology). Blots were developed using the Super Signal Chemiluminescent Substrate (Pierce, Rockford, IL).

ERK-MAP kinase activity assay was performed as described by Dolcet et al. (1999). Kinase activity was assayed on whole-cell lysates using 

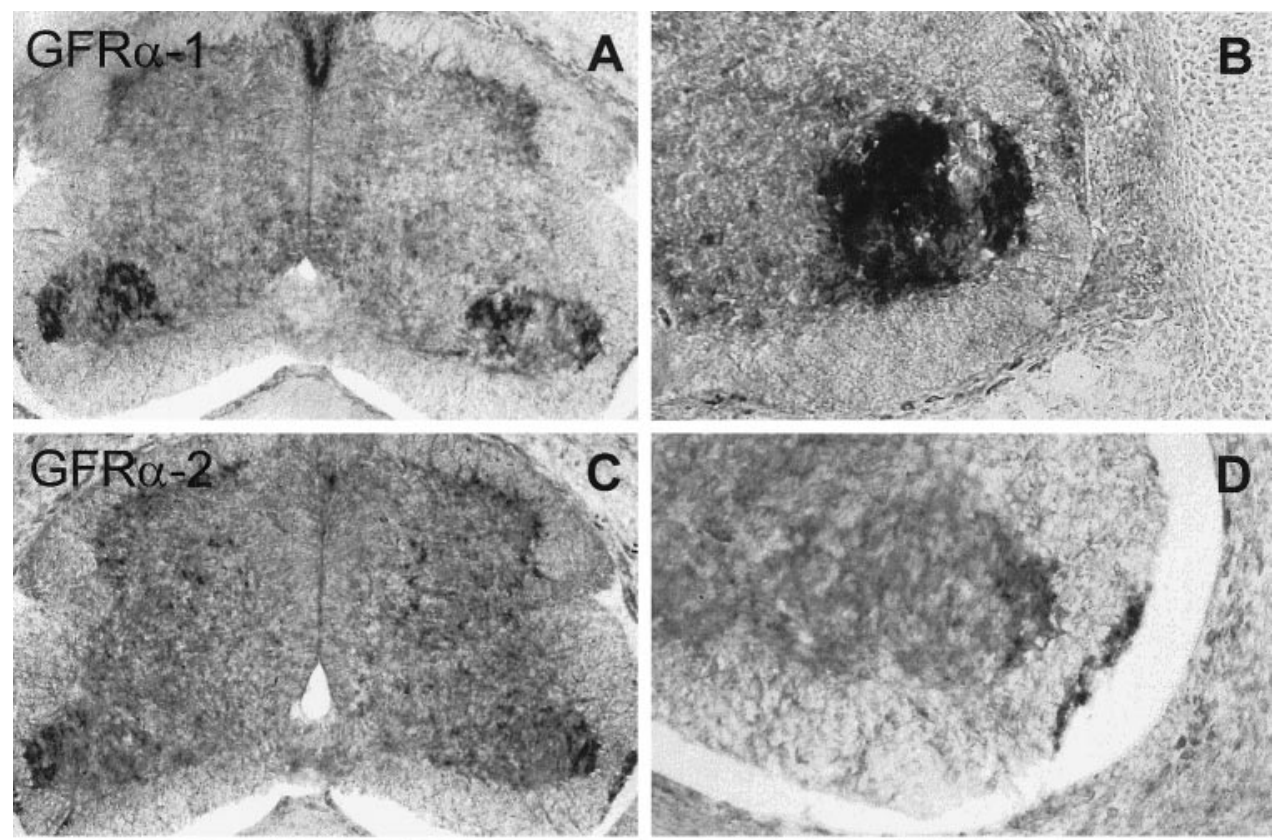

Figure 1. Ret and GFR $\alpha$ receptors are expressed in embryonic chick spinal cord. In situ hybridization analysis of $\mathrm{GRF} \alpha-1$ $(A, B), \mathrm{GRF} \alpha-2(C, D), \mathrm{GRF} \alpha-4(E, F)$, and Ret $(G, H)$ expression in E7.5 chicken. Serial transversal sections through the spinal cord were hybridized to antisense riboprobes against the four receptors. $B, D, F$, and $H$ are amplifications of the lateral motor column showing the expression in MTNs of GRF $\alpha-1, G R F \alpha-2$, GRF $\alpha-4$, and Ret, respectively. Control sense probe did not show any specific patterns of hybridization signal (data not shown).
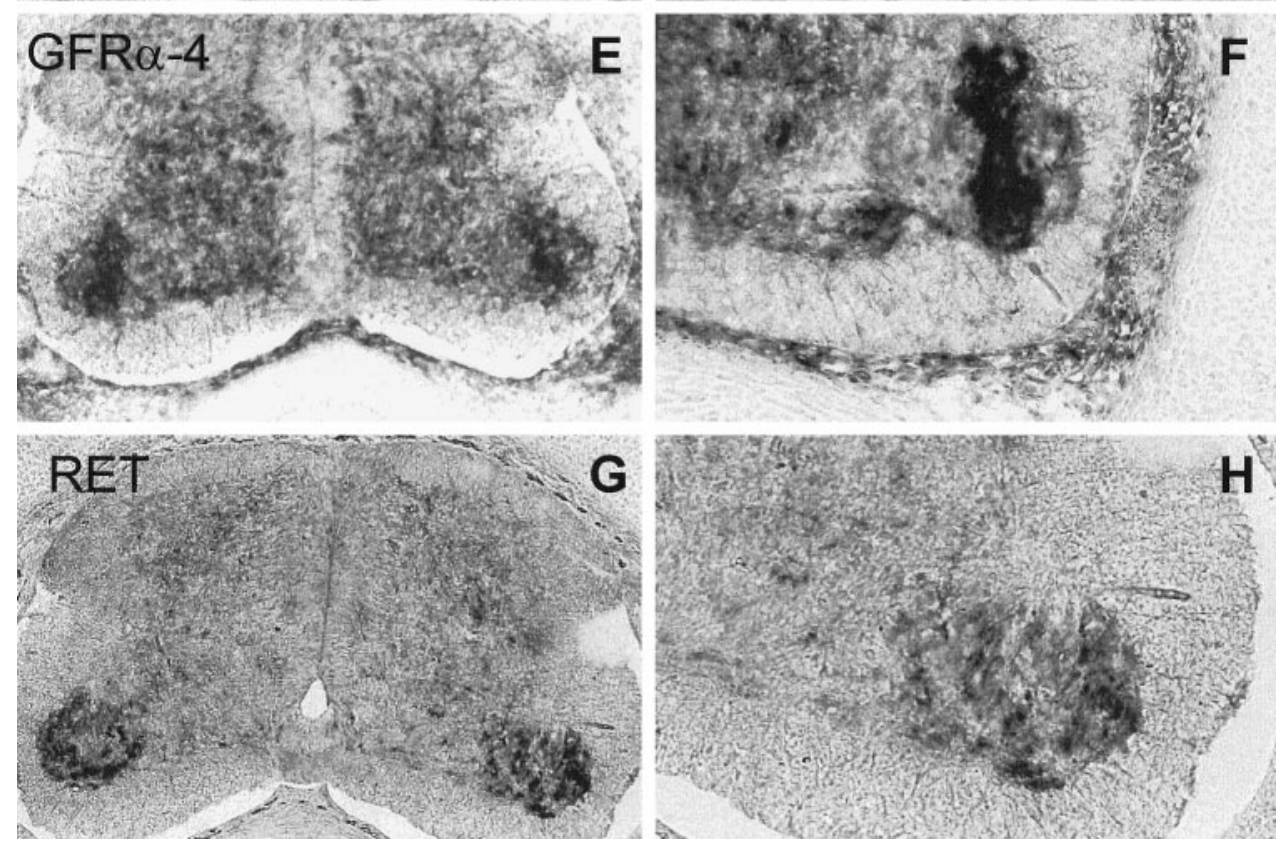

as substrates $\left[\gamma^{32} \mathrm{P}\right]$ ATP (Amersham Pharmacia Biotech) and a specific peptide provided by the BIOTRAK p42/p44 MAP kinase enzyme assay (Amersham Pharmacia Biotech) following the manufacturer's instructions. Incorporation of radioactivity was measured in a scintillation counter. Results were obtained as picomoles of inorganic phosphate incorporated per minute per microgram of protein extract and are expressed in the figures as the fold induction over the activity found in nonstimulated cultures.

Akt activity was performed essentially as described by Khwaja et al. (1998). Briefly, $150 \mu \mathrm{g}$ of total protein was immunoprecipitated with 1 $\mu \mathrm{g}$ of anti-Akt1 antibody (C-20) (Santa Cruz Biotechnology) for $1 \mathrm{hr}$ at $4^{\circ} \mathrm{C}$. Immunocomplexes were collected with protein $\mathrm{G}$ (Sigma), washed, and incubated with $3 \mu \mathrm{Ci}$ of $\left[\gamma^{32} \mathrm{P}\right]$ ATP (Amersham Pharmacia Biotech) and histone H2B (Boehringer Mannheim) as substrates. Reaction was performed for $30 \mathrm{~min}$ at room temperature and stopped by adding sample buffer and boiling for $5 \mathrm{~min}$. Immunocomplexes were resolved by SDS-PAGE. Quantification of H2B phosphorylation was performed by PhosphorImager Analysis (Molecular Dynamics, Sunnyvale, CA).

\section{RESULTS}

\section{Ret and GFR $\alpha$ receptors are expressed in embryonic chicken MTNs in vivo and in vitro}

GDNF family of neurotrophic factors mediate neuronal survival through a receptor complex composed of Ret and a member of the GFR $\alpha$ family of GPI-linked receptors (GFR $\alpha-1$, GFR $\alpha-2$, and GFR $\alpha$-4) (Jing et al., 1996; Buj-Bello et al., 1997; Enokido et al., 1998; Trupp et al., 1998). Because we wanted to study whether this family of neurotrophic factors promoted cell survival in our culture system, we were first interested to know whether the functional receptors were present in the corresponding embryonic day in chicken spinal cord MTNs. Thus, in situ hybridization analysis using antisense riboprobes specific for each of the receptors were performed in E7.5 chicken sections. In the spinal cord, low-to-moderate levels of Ret and moderate-to-high levels of 
A

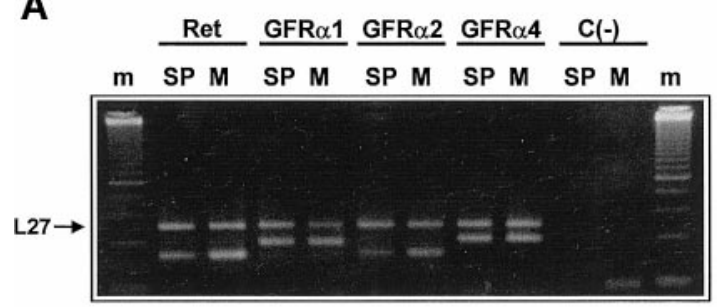

B

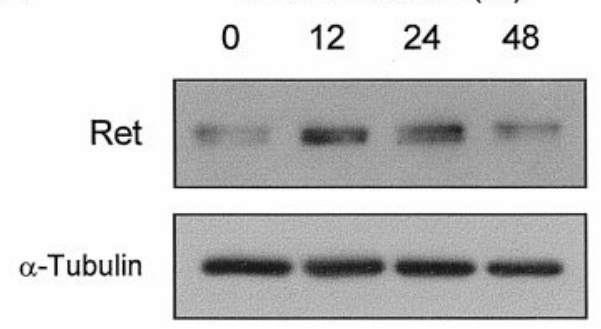

C

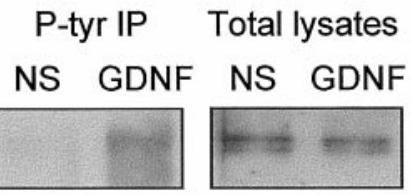

Figure 2. Ret and GFR $\alpha$ receptors are expressed in cultured MTNs. $A$, Agarose gel showing the RT-PCR products for Ret, GFR $\alpha-1$, GFR $\alpha-2$, and GFR $\alpha-4$ in E7.5 spinal cord $(S P)$ and $48 \mathrm{hr}$ cultured MTNs $(M)$. Coamplification of the L27 mRNA (top band in each lane) serves as an internal control. All RNAs were present at similar levels in spinal cord and cultured MTNs, and for all, except GFR $\alpha-4$, there was an enrichment of these transcripts in cultured MTNs. Control reactions performed without reverse transcriptase synthesis $[C(-)]$ show that there was no detectable contamination by genomic DNA. $m$ corresponds to the $50 \mathrm{bp}$ molecular size marker (Amersham Pharmacia Biotech). The same results were obtained without L27 amplification (data not shown). B, Western blot analysis of Ret expression in 0, 12, 24, and $48 \mathrm{hr}$ MEX-cultured MTNs. After these periods of time in culture, cells were lysed, and protein extracts were analyzed by Western blot with an anti-c-Ret antibody. To assess the protein content in each lane, membranes were stripped and reprobed with an anti- $\beta$-tubulin antibody. $C$, GDNF induces Ret tyrosine phosphorylation in MTNs. Cultures were deprived of MEX for $5 \mathrm{hr}$ and then treated with medium containing no additions (NS) or $100 \mathrm{ng} / \mathrm{ml}$ GDNF. After $7 \mathrm{~min}$, cultures were lysed. Western blot of phospho-tyrosine immunoprecipitates (left) or total lysates (right) were probed with an anti-Ret antibody.

GFR $\alpha-1$, GFR $\alpha-2$, and GFR $\alpha-4$ expression were observed in the ventral horn in which MTN cell bodies are located (Fig. 1). The GFR $\alpha-1$ and GFR $\alpha-4$ expression patterns were found to be complementary, and GFR $\alpha$-2-positive cells were found in the peripheral area of the ventral horn. This expression pattern suggests that the GFR family receptors could be expressed in different MTN subpopulations located in the ventral horn, whereas Ret expression was homogeneously distributed in this spinal cord area (Fig. 1).

To investigate further the expression of these receptors in our system, MTNs were cultured in the presence of MEX for $48 \mathrm{hr}$.
After this period of time, we used semiquantitative RT-PCR with specific primers to detect Ret, GFR $\alpha-1$, GFR $\alpha-2$, and GFR $\alpha-4$ mRNA. Figure $2 A$ shows that the four transcripts were present in cultured MTNs with levels similar to those detected in the E7.5 chicken dissociated spinal cord, suggesting that, after $48 \mathrm{hr}$ in culture, MTNs are still expressing all these genes. Moreover, we could also detect an enrichment of Ret, GFR $\alpha-1$, and GFR $\alpha-2$ mRNA levels in the cultured MTN with respect to the entire spinal cord. This is probably caused by an enrichment of cells expressing these genes during the MTN purification process. Furthermore, we were able to detect the expression of Ret protein in cultured MTNs by Western blot analysis. The expression increased with time in culture, and the maximum levels were observed after $24 \mathrm{hr}$ (Fig. 2B). Thereafter, the levels tend to slightly decrease (Fig. 2B). Moreover, we also investigated the ability of GDNF to induce Ret tyrosine phosphorylation. Thus, after GDNF stimulation, cells were lysated and immunoprecipitated with an anti-phospho-tyrosine antibody. Figure $2 C$ shows that cultures treated with GDNF contained tyrosinephosphorylated Ret protein, whereas nonstimulated control cultures did not. We can conclude that GFR $\alpha$ family of receptors and Ret are expressed in chicken spinal cord MTNs both in vivo and in vitro and that GDNF treatment is able to activate Ret in cultured MTNs.

\section{GDNF, NTN, and PSP promote chick MTN survival in culture}

To analyze the effect of GDNF family of neurotrophic factors on chicken spinal cord MTN survival in culture, MTNs were isolated from E5.5 embryos essentially as described by Comella et al. (1994). Isolated MTNs are able to survive in culture in the presence of a saturating concentration $(300 \mu \mathrm{g} / \mathrm{ml})$ of muscle extract (MEX) (Comella et al., 1994). However, when MTN were cultured in the absence of MEX, $<30 \%$ of the cells initially plated remained alive after $36 \mathrm{hr}$ in culture (data not shown). To study the ability of GDNF, NTN, and PSP to promote MTN survival, MTNs were cultured in the presence of MEX for $2 \mathrm{~d}$. Afterward, the culture medium was replaced and the different conditions were established. On readdition of a medium containing $10 \mathrm{ng} / \mathrm{ml} \mathrm{GDNF}$, NTN, or PSP, $\sim 90 \%$ of the MTNs remained alive after an additional $24 \mathrm{hr}$ of culture (Fig. $3 A$ ). These survival percentages were comparable with those observed in cultures supplemented with MEX $(94.7 \pm 6.2)$. However, when they were deprived of MEX and maintained in the basal medium (no extract medium, NE), significantly lower percentages of MTNs $(\sim 60 \%)$ survived. The survival-promoting effect of GDNF family of neurotrophic factors was clearly dose-dependent (Fig. 3B). Concentrations above $100 \mathrm{pg} / \mathrm{ml}$ were saturating, and $\sim 90 \%$ of viable MTNs were maintained. These results showed that GDNF family members are able to maintain the survival of chicken cultured MTNs to approximately the same level of that observed with MEX. No major morphological differences were observed between MTNs treated with MEX and those treated with any of the different trophic factors assayed.

In these survival experiments, we found that saturating concentrations of a single factor rescued $\sim 90 \%$ of the cultured MTNs. Because the expression of the GFR $\alpha$ receptors is distributed in different neuronal subpopulations in the spinal cord, we were interested to know whether combinations of factors used at $10 \mathrm{pg} / \mathrm{ml}$ would improve MTN survival. Figure $3 C$ shows that all of the combinations of factors studied did an additive effect on cell survival. This result suggests that, at high concentrations, a 
Figure 3. GDNF family of neurotrophic factors promote MTN survival in culture. $A$, Percentages of MTN survival after 24 $\mathrm{hr}$ in the presence of $10 \mathrm{ng} / \mathrm{ml}$ GDNF, NTN, or PSP. $B$, Dose-dependence curves of MTN survival after $24 \mathrm{hr}$ in the presence of different doses of GDNF, NTN, or PSP. $C$, In the left half, bars show the percentage of MTN survival after $24 \mathrm{hr}$ in the presence of $10 \mathrm{pg} / \mathrm{ml}$ GDNF, NTN, or PSP. In the right half, bars show the percentage of survival in cultures treated during $24 \mathrm{hr}$ with different combinations of factors, all of them added at doses of 10 $\mathrm{pg} / \mathrm{ml} . D$, Percentage of MTN survival after $24 \mathrm{hr}$ in $10 \mathrm{ng} / \mathrm{ml}$ GDNF-, NTN-, or PSP-treated cultures in the absence ( filled bars) or presence (open bars) of $1 \mathrm{U} / \mathrm{ml}$ PIPLC. Broken lines in $A-D$ show survival of cells in sibling control cultures maintained in the presence (top line, $M E X$ ) or absence (bottom line, NE) of MEX culture medium for the same culture period. Values are the mean \pm SEM of eight wells from a representative experiment that was repeated twice more with results comparable with those presented. Asterisk in $C$ indicates that the values are significantly different $(p<0.01)$ between cultures treated with a single factor and cultures treated with a combination of factors as determined by the Student's $t$ test. Asterisk in $D$ indicates survival values significantly different $(p<0.01)$ when comparing cultures treated with PIPLC or not as determined by the Student's $t$ test.

\section{A}

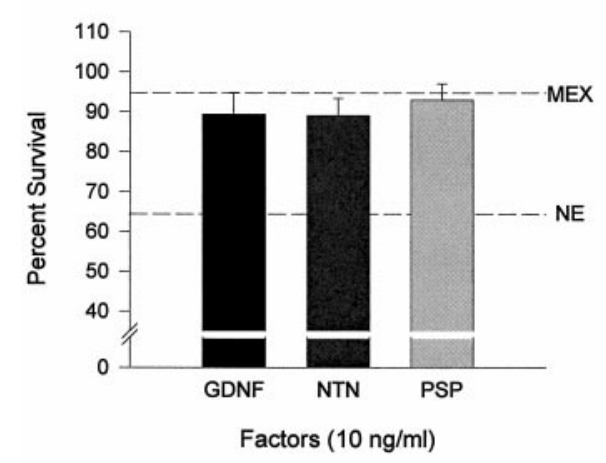

C

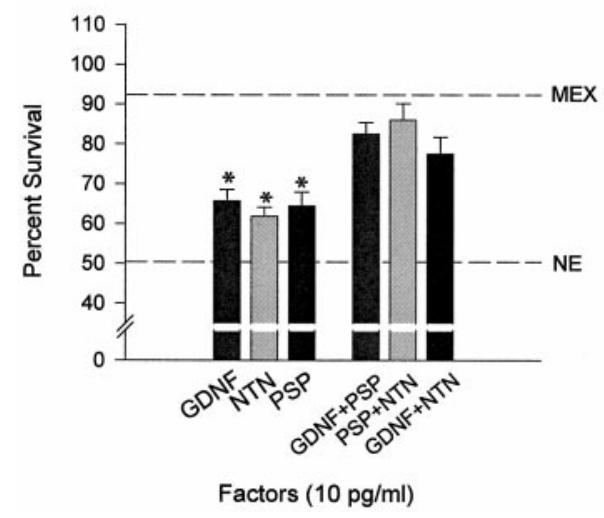

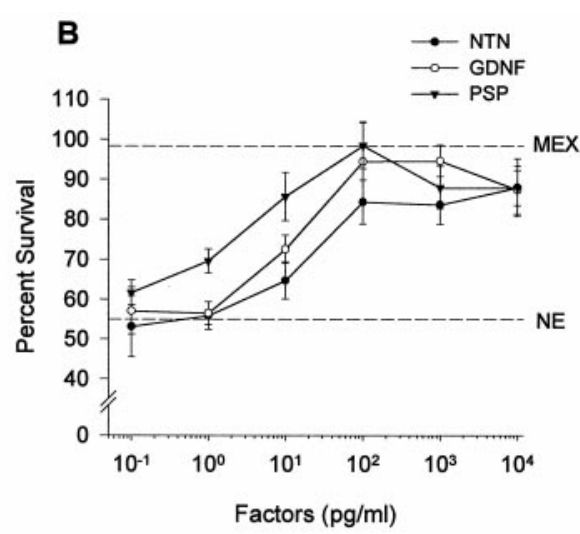

D

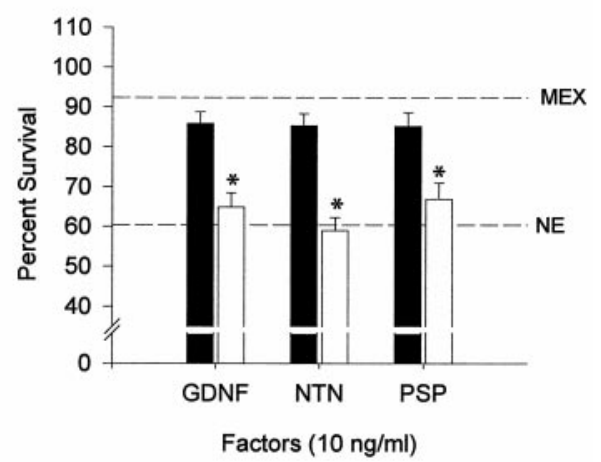

Figure 4. Effect of GDNF family of neurotrophic factors treatment on the activation of MEK, ERK, and Akt. MTNs were cultured for $48 \mathrm{hr}$ in the presence of MEX, deprived of MEX for $5 \mathrm{hr}$, and then stimulated as indicated for $7 \mathrm{~min}$ with $50 \mathrm{ng} / \mathrm{ml}$ (for Western blot analysis) or $100 \mathrm{ng} / \mathrm{ml}$ (for kinase activity) GDNF, NTN, or PSP. After treatment, cells were lysed, and protein extracts were obtained. $A$, Protein extracts were analyzed by Western blot with an anti-P-MEK1/2 antibody $(\alpha-P-M E K 1 / 2)$ or with an antiP-ERK1/2 antibody $(\alpha-P$-ERK1/2) and stripped and reprobed with an antiMEK1/2 antibody $(\alpha-M E K 1 / 2)$ or an antipan-ERK antibody $(\alpha-p a n-E R K)$. NS indicates nonstimulated control cultures. Arrows labeled $P$-MEK1/2, MEK1/2, $P$-ERK2, and ERK2 indicate the position of the phosphorylated and nonphosphorylated forms of MEK1/2 and ERK2 proteins, respectively. Protein extracts were subjected to an ERK-MAP kinase assay. Results are expressed as fold induction over basal activity. Asterisk indicates survival values significantly different $(p<$ A
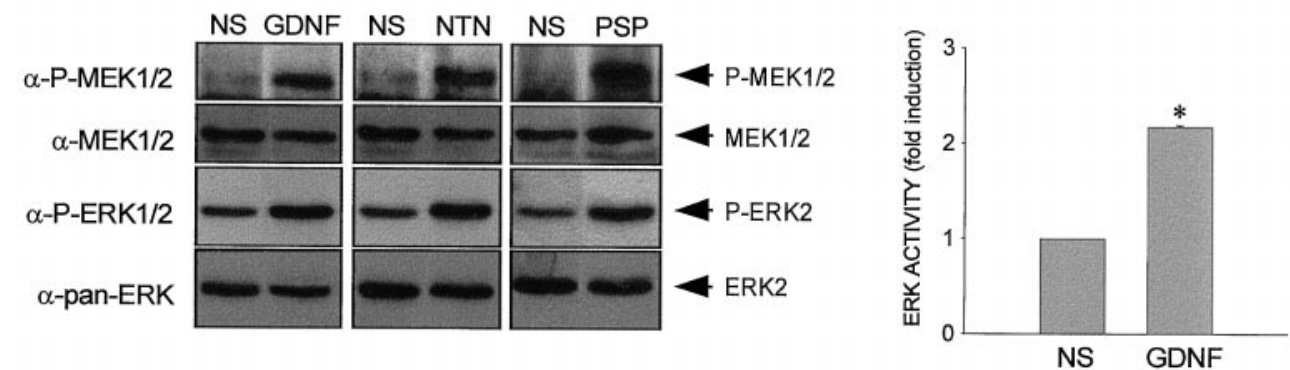

B 0.01 ) when comparing cultures treated with GDNF or not as determined by the

Student's $t$ test. $B$, Protein extracts were analyzed by Western blot with an anti-P-Akt antibody $(\alpha-P-A k t)$ and stripped and reprobed with an anti-Akt antibody $(\alpha-A k t)$. NS indicates nonstimulated control cultures. Arrows labeled $P$-Akt and Akt show the position of the phosphorylated and nonphosphorylated forms of Akt protein, respectively. Protein extracts were subjected to immunoprecipitation with an anti-Akt antibody, and the immunoprecipitates were tested by an Akt kinase assay. Results are expressed as fold induction over basal activity. Asterisk indicates survival values significantly different $(p<$ 0.01 ) when comparing cultures treated with GDNF or not as determined by the Student's $t$ test. 


\section{A}
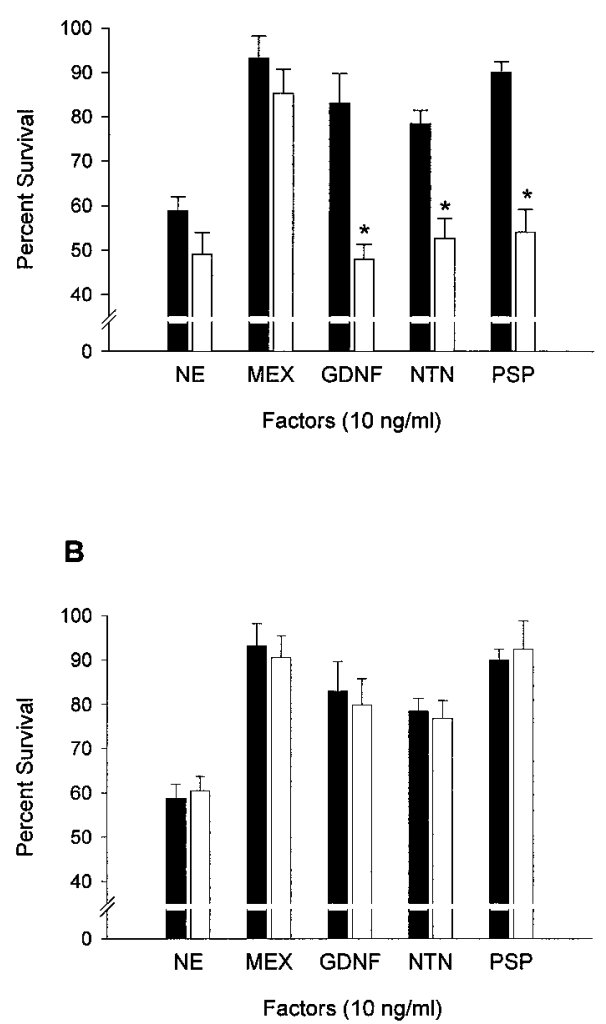

Figure 5. Effects of MEK and PI 3-kinase inhibitors on MTN survival mediated by GDNF family of neurotrophic factors. $A$, MTN survival in cultures treated during $24 \mathrm{hr}$ in basal medium (NE), MEX, or $10 \mathrm{ng} / \mathrm{ml}$ GDNF, NTN, or PSP medium in the absence (filled bars) or presence (open bars) of $50 \mu \mathrm{M}$ LY 294002. Asterisk indicates survival values significantly different $(p<0.01)$ when comparing cultures treated with LY 294002 or not as determined by the Student's $t$ test. $B$, MTN survival in cultures treated during $24 \mathrm{hr}$ in basal medium (NE), MEX, or $10 \mathrm{ng} / \mathrm{ml}$ GDNF, NTN, or PSP medium in the absence (filled bars) or presence (open bars) of $20 \mu \mathrm{M}$ PD 98059. No significant differences in cell survival were found after this MEK inhibitor treatment.

single factor could also promote survival acting through any of the GFR $\alpha$ receptors.

To know whether GPI-linked proteins are normally required for the survival response of MTNs to GDNF, NTN, and PSP, we treated $48 \mathrm{hr}$ cultured MTNs with phosphoinositide-specific phospholipase C (PIPLC), an enzyme that specifically cleaves GPI linkages (Koke et al., 1991). PIPLC treatment reduced the number of surviving neurons in the presence of GDNF, NTN, or PSP to the level observed in basal medium $(\mathrm{NE})(\sim 60 \%)$ (Fig. $3 D)$. However, addition of PIPLC to NE-, MEX-, or BDNFsupplemented cultures did not have any effect on MTN survival (data not shown). All of these results suggest that PIPLC treatment eliminated the specific survival response of cultured MTNs to GDNF family of neurotrophic factors, indicating the involvement of the GPI-linked receptors in this process.

\section{GDNF family of neurotrophic factors activates PI 3- kinase and ERK-MAP kinase pathways in cultured MTNs}

Neurotrophic factors, such as neurotrophins, induce tyrosine phosphorylation of Trk receptors and the activation of several intracellular pathways in several neuronal populations, including chicken MTNs (Dolcet et al., 1999). Two of these pathways,
ERK-MAP kinase and PI 3-kinase, are the best characterized signaling pathways activated by Trk receptors, and they have been related in neuronal differentiation and survival (Kaplan and Miller, 1997). To know whether GDNF family of neurotrophic factors induces activation of ERK-MAP kinase and PI 3-kinase intracellular signaling pathways, MTNs were cultured in the presence of MEX during $48 \mathrm{hr}$. Then, cells were washed and stimulated with $50 \mathrm{ng} / \mathrm{ml} \mathrm{GDNF}$, NTN, and PSP for $7 \mathrm{~min}$. MTNs were lysed, and cell lysates were analyzed by immunoblotting using anti-P-MEK, anti-P-ERK antibodies (two kinases of the MAP kinase pathway), and anti-P-Akt antibodies (a well known downstream effector of the PI 3-kinase). Figure 4 shows an increase of tyrosine phosphorylation of MEK, ERK, and Akt after GDNF, NTN, and PSP treatment compared with the basal level observed in nonstimulated cultures. When the same filters were stripped and reprobed with anti-pan-MEK, anti-pan-ERK, and anti-pan-Akt antibodies, bands with similar intensities appeared in nonstimulated and stimulated cultures.

Moreover ERK-MAP kinase and Akt kinase assays were performed in cell lysates of MTNs stimulated with $100 \mathrm{ng} / \mathrm{ml}$ GDNF for $7 \mathrm{~min}$. Results in Figure 4 show that GDNF stimulation caused an induction of Akt (2.8-fold induction) and ERK-MAP kinase (2.1-fold induction) activity when we compared it with the level of kinase activity in nonstimulated cells.

Taking together all of these observations, we conclude that both ERK-MAP kinase and PI 3-kinase pathways could be activated by GDNF, NTN, and PSP, suggesting the possibility that they could transduce the survival effect of these neurotrophic factors on MTNs.

\section{Inhibition of PI 3-kinase, but not ERK-MAP kinase, reverts GDNF family of neurotrophic factors-promoted MTN survival}

To further investigate the role of PI 3-kinase and ERK-MAP kinase intracellular pathways mediating the survival-promoting effect of GDNF family members, we analyzed the effect of the PI 3-kinase inhibitor LY 294002 and the MEK inhibitor PD 98059 on cultured MTNs. Cells were cultured for $2 \mathrm{~d}$ in the presence of MEX, washed with L15H, and switched to culture medium supplemented with neurotrophic factors $(10 \mathrm{ng} / \mathrm{ml})$ in the presence or absence of LY 294002 (Fig. 5A) or PD 98059 (Fig. 5B). After $24 \mathrm{hr}$, evaluation of MTN survival showed that LY 204002, but not PD 98059, reverted the survival-promoting effect mediated by GDNF, NTN, and PSP (Fig. 5). The effect of LY 294002 was dose-dependent (data not shown) and, at $50 \mu \mathrm{M}$, the number of surviving neurons was comparable with the one obtained in control cultures maintained in basal medium (NE). The same dose of LY 294002 was also able to prevent the increase in the Akt phosphorylation levels after GDNF, NTN, or PSP stimulation, demonstrating the functional blockade of PI 3-kinase activity (Fig. 6B).

On the other hand, Western blot analysis of $20 \mu \mathrm{M}$ PD 98059treated cultures showed that ERK phosphorylation was prevented after neurotrophic factor treatment (Fig. 6A). At the same dose of PD 98059, the level of MTN survival was not affected, and the number of surviving neurons after $24 \mathrm{hr}$ of treatment was the same as the one obtained in control cultures (MEX, GDNF, NTN, or PSP) (Fig. 5B). Moreover, the $20 \mu \mathrm{M}$ dose of PD 98059 was unable to alter the level of phosphorylation of Akt after GDNF, NTN, or PSP stimulation (data not shown). Together, these results suggest that the downstream elements activated by ERK-MAP kinases are not necessary for GDNF-, NTN-, and 
A PD $98059(A)$ or LY $294002(B)$, and then stimulated $(+)$ or not $(-)$ for $7 \mathrm{~min}$ with $50 \mathrm{ng} / \mathrm{ml}$ GDNF, NTN, or PSP. After treatment, cells were lysed, and protein extracts were analyzed by Western blot with an anti-phospho-ERK1/2 antibody $(\alpha-P-E R K 1 / 2)$ or an anti-phospho-Akt antibody $(\alpha-P-A k t)$ and stripped and reprobed with an anti-pan-ERK antibody $(\alpha-p a n-E R K)$ or with an anti-Akt antibody $(\alpha-A k t)$. Arrows labeled $P-E R K 2, E R K 2, P-A k t$, and $A k t$ indicate the position of the phosphorylated and nonphosphorylated forms of ERK2 and Akt, respectively.
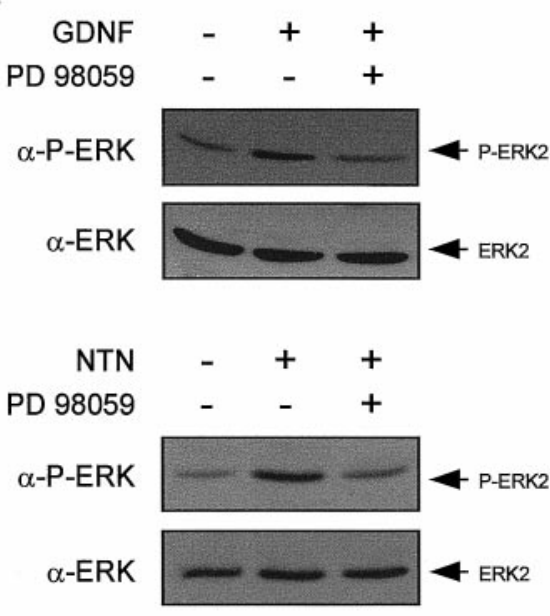

B
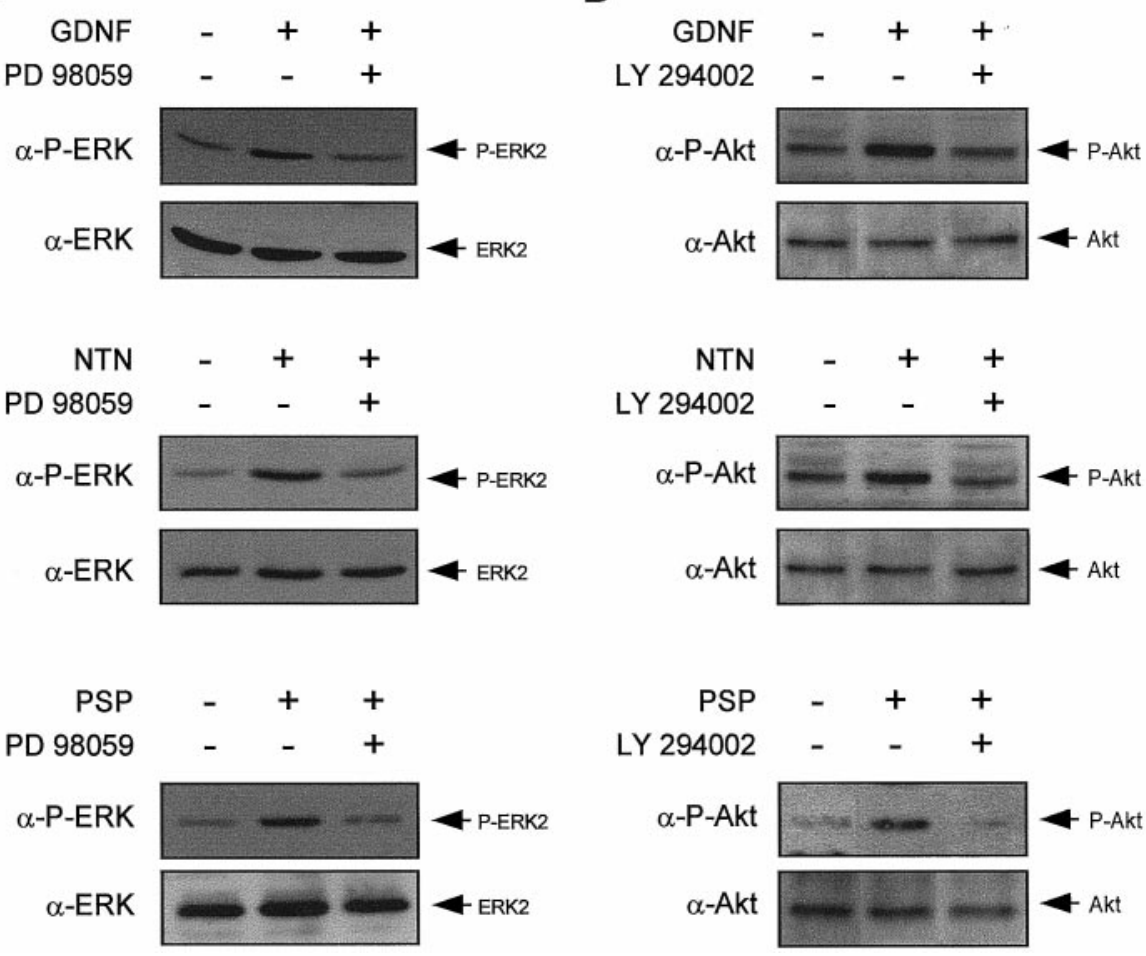

PSP-mediated survival; however, the PI 3-kinase pathway is one of the key elements involved in the survival process induced by the GDNF family of neurotrophic factors.

To asses whether LY 294002 suppresses the survival effects of these neurotrophic factors inducing the same kind of neuronal cell death as that observed after trophic factor deprivation (i.e., MEX withdrawal), we have quantified the percentage of apoptotic MTNs after LY 294002 treatment. Experiments were performed with the Hoechst 33258 dye, which binds specifically to the chromatinic DNA. Apoptotic cells display a highly condensed DNA that is normally fragmented in two or more chromatin aggregates (Fig. 7A). In cultures grown in the presence of MEX, GDNF, NTN, or PSP, the percentage of cells displaying this morphological feature was found to be $<6 \%$. However, after 15 hr of MEX deprivation or $50 \mu \mathrm{M}$ LY 294002 treatment, the percentage of apoptotic cells greatly increased, and the percentage of apoptotic cells was found to be doubled when compared with their LY 294002 untreated counterparts (Fig. 7B). These results suggest that LY 294002 reverted the trophic effect promoted by GDNF, NTN, or PSP, inducing an apoptotic cell death process at the same dose that blocked Akt phosphorylation induced by these neurotrophic factors.

It has been reported previously that apoptotic cell death is accompanied by the enzymatic activity of a family of proteases referred as to caspases (for review, see Cryns and Yuan, 1998). This activity has been established as a good criteria to characterize the apoptotic cell death in chicken spinal cord MTNs after trophic factor deprivation (Li et al., 1998; Dolcet et al., 1999). To analyze caspase activity in our culture system, we performed an in vitro assay using the fluorogenic substrate DEVD-AFC (Talanian et al., 1997). Once DEVD-AFC is cleaved by caspases, the AFC group is released from the whole molecule, becoming fluorescent (Nicholson et al., 1995). Using this approach, we observed an induction of caspase activity in MEX-deprived cells (NE) when we compared it with the level of caspase activity found in MEXtreated (2.3-fold induction), GDNF-treated (2.6-fold induction), NTN-treated (2-fold induction), or PSP-treated (1.7-fold induction) cultures (Fig. 7C). To know whether LY 294002 treatment on GDNF family-maintained cells induced the same effect on caspase activity as deprived cultures, MTN were treated with GDNF, NTN, or PSP $(10 \mathrm{ng} / \mathrm{ml})$ in the presence or absence of 50 $\mu \mathrm{M}$ LY 294002. Figure $7 C$ shows that the level of caspase activity in LY 294002-treated cultures was similar to that obtained in basal medium $(\mathrm{NE})$-treated cultures and higher $(p<0.01)$ than that obtained in GDNF-, NTN-, or PSP-treated cells. These results suggest that GDNF family of neurotrophic factors inhibit the activation of caspases through a PI 3-kinase-dependent pathway.

\section{DISCUSSION}

We have shown in the present study that the members of GDNF family of neurotrophic factors promote MTN survival through the activation of the PI 3-kinase intracellular signaling pathway. These neurotrophic factors are potent survival factors for different neuronal populations, including spinal cord MTNs (Henderson et al., 1994; Oppenheim et al., 1995; Yan et al., 1995; Klein et al., 1997; Horger et al., 1998; Milbrandt et al., 1998). In our culture system, GDNF, NTN, and PSP promoted the survival of MTNs deprived of MEX. The effect was dose-dependent, and it was reverted by adding PIPLC in the culture medium. This enzyme specifically cleaves the GPI linkage of the GFR $\alpha$ to the cell membrane, thus precluding the activation of Ret (Koke et al., 1991). Our results indicated that these neurotrophic factors need to bind to a GPI-linked receptor to do their survival effect on cultured MTNs. It has been described previously that GDNF, NTN, and PSP act through their binding to the GPI-linked coreceptors GFR $\alpha-1$, GFR $\alpha$-2, and GFR $\alpha$-4, respectively (BujBello et al., 1997; Klein et al., 1997; Enokido et al., 1998) (for 
A
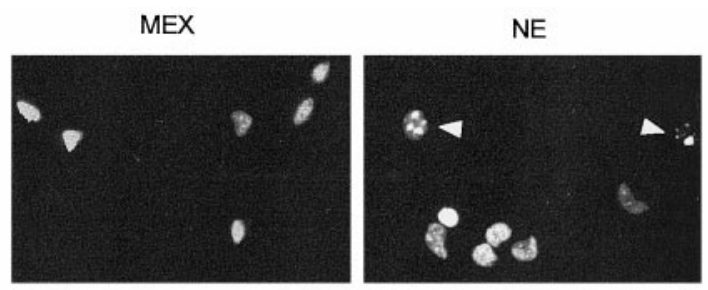

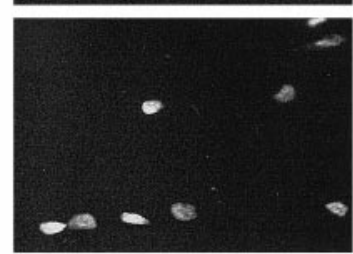

GDNF

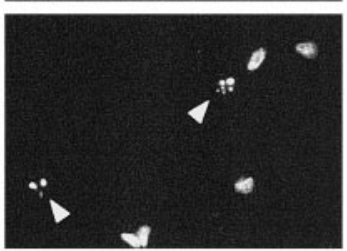

GDNF LY
B

\begin{tabular}{l|c|c}
\multicolumn{2}{c}{ \% of apoptotic cells } \\
LY294002 & - & + \\
\hline GDNF & $5,9 \pm 1$ & $9,8 \pm 1,3$ \\
NTN & $5,3 \pm 0,6$ & $10,5 \pm 1,8$ \\
PSP & $3,5 \pm 0,6$ & $6,7 \pm 0,3$
\end{tabular}

C

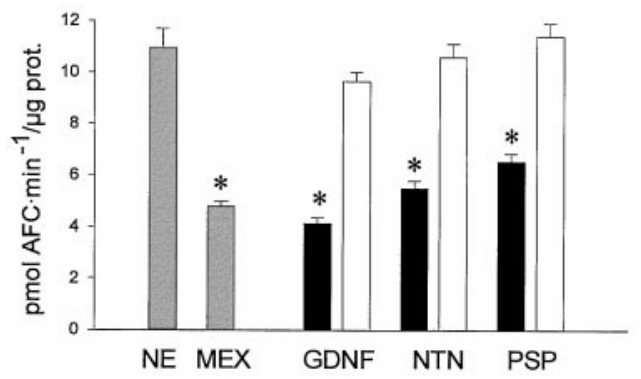

Figure 7. Cell death induced by LY 294002 shared apoptotic features with that observed after MEX deprivation. $A$, MTNs were maintained in culture in the presence of MEX for $48 \mathrm{hr}$. Then, cells were grown for $15 \mathrm{hr}$ in different culture conditions: basal medium without any trophic support (NE); supplemented with MEX; or supplemented with $10 \mathrm{ng} / \mathrm{ml}$ GDNF, NTN, or PSP in the presence or absence of $50 \mu \mathrm{M}$ LY 294002. After this time, MTN nuclei were stained with Hoechst. Representative photomicrographs of cultures treated with basal medium (NE), MEX, GDNF, or GDNF plus LY 294002. B, Percentage of apoptotic cells in each condition. Quantification of apoptotic nuclei was performed as described in Materials and Methods. The percentages in control cultures were $8.5 \pm 2.7$ for NE and 5.9 \pm 1.3 for MEX. $C$, Assay of caspase activity performed in cultures treated for $8 \mathrm{hr}$ with 10 $\mathrm{ng} / \mathrm{ml}$ GDNF, NTN, or PSP in the presence (open bars) or absence (filled bars) of $50 \mu \mathrm{M}$ LY 294002, MEX, or basal medium (NE). At the end of the treatment, cells were lysed, and protein extracts were assayed for its caspase activity as described in Materials and Methods. Results are expressed as $\mathrm{pmol}$ of AFC $\cdot \mathrm{min}^{-1} \cdot \mu \mathrm{g}$ of protein. Asterisk indicates significant differences $(p<0.01)$ on caspase activity between GDNF-, NTN-, or PSP-treated cultures and NE- or GDNF, NTN, or PSP plus LY 294002-treated cultures.

review, see Ibáñez, 1998). In the present work, we also demonstrated the presence of Ret and GFR $\alpha$ family receptors in embryonic chicken spinal cord MTNs both in vivo and in vitro using in situ hybridization and RT-PCR techniques. The presence of
GRF $\alpha-1$ and GFR $\alpha-2$, but not GFR $\alpha-3$, receptors in the ventral horn of rat embryos spinal cord has been demonstrated previously (Yu et al., 1998). Moreover, GFR $\alpha-4$ is expressed in embryonic chicken spinal cord MTNs (Thompson et al., 1998). However, our results demonstrated the presence of these receptors in chicken spinal cord MTNs by both methods. We also show that the distinct GFR $\alpha$ receptors are located on different MTN subpopulations. This situation could not be compatible with the fact that, in the survival experiments, high doses of a single factor were able to promote $\sim 100 \%$ survival of purified MTNs, but at subsaturating concentrations, the combinations of factors always had an additive effect on the survival of these cells. This situation could be explained by the possibility that high doses of any of these factors could also bind to another member of the GFR $\alpha$ family receptors. This cross-talk between the members of both families, neurotrophic factors and receptors, has been described previously by different authors, especially when neuronal survival was assessed by culture methods (Baloh et al., 1998; Enokido et al., 1998; Ibañez, 1998; Trupp et al., 1998). Thus, the studies performed in mutant mice lacking GDNF, NTN, or GFR $\alpha-1$ receptors show moderate or no loss of MTNs number in the trigeminal motor nucleus, the spinal cord, or the facial nucleus (Moore et al., 1996; Sanchez et al., 1996; Cacalano et al., 1998; Heuckeroth et al., 1999). These results, together with the in vitro observations, suggest that it may possible that this cross-talk also exists in vivo. Experiments with double mutant mice lacking more than one of the members of family receptors or of the neurotrophic factors will answer this question.

Little is known about the intracellular signaling pathways triggered by the GDNF family of neurotrophic factors when they activate Ret. In the present work, we show that GDNF, NTN, and PSP increased the phosphorylation of MEK, ERK, and Akt, indicating that the ERK-MAP kinase and the PI 3-kinase intracellular signaling pathways were activated. Moreover, we present evidence that only the blockade of the PI 3-kinase pathway using the PI 3-kinase-specific inhibitor LY 294002 was able to revert the survival effect induced by GDNF, NTN, and PSP. This effect was found at the same doses that prevent the activation of the PI 3-kinase. Moreover, by morphological criteria, MEX deprivation and LY 294002 treatment induce a comparable apoptosis, suggesting that this pathway plays a central role in the survivalpromoting effects elicited by GDNF, NTN, or PSP. Furthermore, these results were reinforced when a specific biochemical parameter, i.e., caspase activity, was measured. We have found that MEX deprivation and LY 294002 treatment increased the level of DEVD-specific caspase activity. On the contrary, when cells were treated with the MEK inhibitor PD 98059, a drug that inhibits the phosphorylation and the ERK-MAP kinase activity, it does not affect MTN survival. It has been demonstrated previously that GDNF and NTN were able to stimulate the activation of ERKMAP kinase and the PI 3-kinase intracellular signaling in sympathetic neurons (Kotzbauer et al., 1996; Creedon et al., 1997). However, in these reports, no evidence about the role of these pathways in mediating survival effects were provided. Our study expands the initial findings in GDNF and NTN to PSP. Moreover, we report that MTN behaves similarly to sympathetic neurons with regard to the stimulation of these intracellular pathways. Therefore, we demonstrate that PI 3-kinase pathway seems to mediate the survival-promoting effects induced by this family of neurotrophic factors. The role of the PI 3-kinase pathway as a mediator of the trophic effects of several trophic factors has been described previously in BDNF-mediated survival of cultured 
cerebellar granule neurons (Nonomura et al., 1996; Shimoke et al., 1997) or spinal cord MTNs (Dolcet et al., 1999), in NGF maintained PC12 or SGC cells (Yao and Cooper, 1995; Crowder and Freeman, 1998), and in cerebellar granule neurons maintained with IGF-1 (D’Mello et al., 1997; Dudek et al., 1997; Miller et al., 1997). However, the present work is the first demonstration of the involvement of the PI 3-kinase pathway in mediating the survival-promoting effects of the GDNF family of neurotrophic factors.

The activation of the ERK-MAP kinase pathway after trophic factor stimulation has been described previously in different neuronal populations, such as MTNs (Becker et al., 1998), cerebellar granule cells (Nonomura et al., 1996), and hippocampal pyramidal neurons (Marsh and Palfrey, 1996). In our culture system, the stimulation by GDNF, NTN, or PSP also increases ERK and MEK phosphorylation and, consequently, the activation of this intracellular pathway. However, the inhibition of this pathway was unable to block the survival-promoting effect caused by GDNF family of neurotrophic factors. The present results are in accordance with those reported by other authors using different approaches in several neuronal systems (Creedon et al., 1996; Marsh and Palfrey, 1996; Virdee and Tolkovsky, 1996; Miller et al., 1997; Soler et al., 1998). These studies suggest that the activation of the ERK-MAP kinase pathway is not involved in the cellular events directly related with cell survival. However, the activation of this pathway could be an important step in mediating neuronal differentiation. In that sense, it has been reported the involvement of this pathway mediating neurite outgrowth, which is one of the indicators for neuronal differentiation (Qiu and Green, 1992; Cowley et al., 1994; Fukuda et al., 1995; Pang et al., 1995; Creedon et al., 1996).

In conclusion, our work demonstrated the involvement of the PI 3-kinase intracellular pathway mediating neuronal survival after GDNF family of neurotrophic factors stimulation. It seems that this will be a general process in signaling transduction mechanisms of different neurotrophic factors on many neuronal populations. The involvement of other pathways mediating different processes others than neuronal survival could allow us to understand the mechanisms by which neurotrophic factors regulate diverse neuronal responses.

\section{REFERENCES}

Allsopp TE, Robinson M, Wyatt S, Davies AM (1993) Ectopic trkA expression mediates a NGF survival response in NGF-independent sensory neurons but not in parasympathetic neurons. J Cell Biol 123:1555-1566.

Baloh RH, Tansey MG, Lampe PA, Fahrner TJ, Enomoto H, Simburger KS, Leitner ML, Araki T, Johnson Jr EM, Milbrandt J (1998) Artemin, a novel member of the GDNF ligand family, supports peripheral and central neurons and signals through the GFR $\alpha 3$-Ret receptor. Neuron 21:1291-1302.

Becker E, Soler RM, Yuste VJ, Gine E, Sanz-Rodriguez C, Egea J, Martin-Zanca D, Comella JX (1998) Development of survival responsiveness to brain-derived neurotrophic factor, neurotrophin 3 and neurotrophin $4 / 5$, but not to nerve growth factor, in cultured motoneurons from chick embryo spinal cord. J Neurosci 18:7903-7911.

Bradford MM (1976) A rapid and sensitive method for the quantitation of microgram quantities of protein utilising the principle of protein-dye binding. Anal Biochem 72:248-254.

Buj-Bello A, Buchman VL, Horton A, Rosenthal A, Davies AM (1995) GDNF is an age-specific survival factor for sensory and autonomic neurons. Neuron 15:821-828.

Buj-Bello A, Adu J, Piñon LGP, Horton T, Thompson J, Rosenthal A, Chinchetru M, Buchman VL, Davies AM (1997) Neurturin responsiveness requires a GPI-linked receptor and the Ret receptor tyrosine kinase. Nature 387:721-724.
Cacalano G, Fariñas I, Wang LC, Hagler K, Forgie A, Moore M, Armanini M, Phillips H, Ryan AM, Reichardt LF, Hynes M, Davies A, Rosenthal A (1998) GFR $\alpha-1$ is an essential receptor component for GDNF in the developing nervous system and kidney. Neuron 21:53-62.

Chomczynski P, Sacchi N (1987) Single-step method of RNA isolation by acid guanidinium thiocyanate-phenol-chloroform extraction. Anal Biochem 162:156-159.

Comella JX, Sanz-Rodriguez C, Aldea M, Esquerda JE (1994) Skeletal muscle-derived trophic factors prevent motoneurons from entering an active cell death program in vitro. J Neurosci 14:2674-2686.

Cowley S, Paterson H, Kemp P, Marshall CJ (1994) Activation of MAP kinase kinase is necessary and sufficient for PC12 differentiation and for transformation of NIH 3t3 cells. Cell 77:841-852.

Creedon DJ, Johnson EM, Lawrence JC (1996) Mitogen-activated protein kinase-independent pathways mediate the effects of nerve growth factor and cAMP on neuronal survival. J Biol Chem 271:20713-20718.

Creedon DJ, Tansey MG, Baloh RH, Osborne PA; Lampe PA, Fahrner T, Heuckeroth RO, Milbrandt J, Johnson Jr EM (1997) Neurturin shares receptors and signal transduction pathways with glial cell line-derived neurotrophic factor in sympathetic neurons. Proc Natl Acad Sci USA 94:7018-7023.

Crowder RJ, Freeman RS (1998) Phosphatidylinositol 3-kinase and Akt protein kinase are necessary and sufficient for the survival of nerve growth factor-dependent sympathetic neurons. J Neurosci 18:2933-2943.

Cryns V, Yuan J (1998) Proteases to die for. Genes Dev 12:1551-1571.

D'Mello SR, Borodezt K, Soltoff SP (1997) Insulin-like growth factor and potassium depolarization maintain neuronal survival by distinct pathways: possible involvement of PI 3-kinase in IGF-1 signaling. J Neurosci 17:1548-1560.

Dolcet X, Egea J, Soler RM, Martin-Zanca D, Comella JX (1999) Activation of PI 3-kinase, but not ERK MAP kinases, is necessary to mediates BDNF-induced motoneuron survival. J Neurochem 73:521-531.

Dudek H, Datta SR, Franke TF, Bimbaum MJ, Yao M, Cooper GM, Segal RA, Kaplan DR, Greenberg ME (1997) Regulation of neuronal survival by the serine-threonine protein kinase Akt. Science 275:661-665.

Durbec P, Marcos-Gutierrez CV, Kilkenny C, Grigoriou M, Wartiowaara K, Suvantro P, Smith D, Ponder B, Costantini F, Saarma M, Sariola H, Pachnis V (1996) GDNF signalling through the Ret receptor tyrosine kinase. Nature 381:789-793.

Enokido Y, de Sauvage F, Hongo JA, Ninkita N, Rosenthal A, Buchman VL, Davies AM (1998) GFR $\alpha-4$ and the tyrosine kinase Ret form a functional receptor complex for persephin. Curr Biol 8:1019-1022.

Enomoto H, Araki T, Jackman A, Heuckeroth RO, Snider WD, Johnson Jr EM, Milbrandt J (1998) GRF $\alpha$-1 deficient mice have deficits in the enteric nervous system and kidneys. Neuron 21:317-324.

Fukuda M, Gotoh Y, Tachibana T, Dell K, Hattori S, Yoneda Y, Nishida E (1995) Induction of neurite outgrowth by MAP kinase in PC12 cells. Oncogene 11:239-244.

Henderson CE, Phillips HS, Pollock RA, Davies AM, Lemeulle C, Armanini M, Simpson LC, Moffet B, Vandlen RA, Koliatsos VE, Rosenthal A (1994) GDNF: a potent survival factor for motoneurons present in peripheral nerve and muscle. Science 266:1062-1064.

Heuckeroth RO, Enomoto H, Grider JR, Golden JP, Hanke JA, Jackman A, Molliver DC, Bardgett ME, Snider WD, Johnson Jr EM, Milbrandt J (1999) Gene targeting reveals a critical role for neurturin in the development and maintenance of enteric, sensory, and parasympathetic neurons. Neuron 22:253-263.

Horger BA, Nishimura MC, Armanini MP, Wang LC, Poulsen, KT, Rosenblad C, Kirik D, Moffat B, Simmons L, Johnson Jr E, Milbrandt J, Rosenthal A, Bjorklund A, Vandlen RA, Hynes MA, Phillips H (1998) Neurturin exerts potent actions on survival and function of midbrain dopaminergic neurons. J Neurosci 18:4929-4937.

Ibáñez CF (1998) Emerging themes in structural biology of neurotrophic factors. Trends Neurosci 21:438-444.

Jing S, Wen D, Yu Y, Holst PL, Luo Y, Fang M, Tamir R, Antonio L, Hu Z, Cupples R, Louis JC, Hu S, Altrock BW, Fox GM (1996) GDNFinduced activation of the Ret protein tyrosine kinase is mediated by GDNFR- $\alpha$, a novel receptor for GDNF. Cell 85:1113-1124.

Kaplan DR, Miller FD (1997) Signal transduction by the neurotrophin receptors. Curr Opin Cell Biol 9:213-221.

Khwaja A, Lehman K, Marte BM, Downward J (1998) Phosphoinositide 
3-kinase induces scattering and tubulogenesis in epithelial cells through a novel pathway. J Biol Chem 273:18793-18801.

Klein RD, Sherman D, Ho WH, Stone D, Bennett GL, Moffat B, Vandlen R, Simmons L, Gu Q, Hongo JA, Devaux B, Poulsen K, Armanini M, Nozaki C, Asai N, Goddard A, Phillips H, Henderson CE, Takahashi M, Rosenthal A (1997) A GPI-linked protein that interacts with Ret to form a candidate neurturin receptor. Nature 387:717-721.

Koke JA, Yang M, Henner DJ, Volwerk JJ, Griffin OH (1991) Highlevel expression in Escherichia coli and rapid purification of phosphatidylinositol-specific phospholipase C from Bacillus cereus and Bacillus thuringiensis. Protein Expr Purif 2:51-58.

Kotzbauer PT, Lampe PA, Heuckeroth, RO, Golden JP, Creedon DJ, Johnson Jr EM, Milbrandt J (1996) Neurturin, a relative of glial-cellline-derived neurotrophic factor. Nature 384:467-470.

Li L, Prevette D, Oppenheim RW, Milligan CE (1998) Involvement of specific caspases in motoneuron cell death in vivo and in vitro following trophic factor deprivation. Mol Cell Neurosci 12:157-167.

Lin LF, Doherty DH, Lile, JD, Bektesh S, Collins F (1993) GDNF: A glial cell line-derived neurotrophic factor for midbrain dopaminergic neurons. Science 260:1130-1132.

Marsh HN, Palfrey HC (1996) Neurotrophin-3 and brain-derived neurotrophic factor activate multiple signal transduction events but are not survival factors for hippocampal pyramidal neurons. J Neurochem 67:952-963.

Maxwell GD, Reid K, Elefanty A, Bartlett PF, Murphy M (1996) Glial cell line-derived neurotrophic factor promotes the development of adrenergic neurons in mouse neural crest cultures. Proc Natl Acad Sci USA 93:13274-13279.

Mildrandt J, de Sauvage FJ, Farçhrner TJ, Baloh RH, Leitner ML, Tansey MG, Lampe PA, Heuckeroth RO, Kotzbauer, PT, Simburger KS, Golden J, Davies JA, Vejsada R, Kato AC, Hynes M, Sherman D, Nishimura M, Wang LC, Vandlen R, Moffat B, Klein RD, Poulsen K, Gray C, Garces A, Henderson CE, Phillips H, Johnson Jr EM (1998) Persephin a novel neurotrophic factor related to GDNF and Neurturin. Neuron 20:245-253.

Miller TM, Tansey MG, Johnson EM, Creedon DJ (1997) Inhibition of phosphatidylinositol 3-kinase activity blocks depolarization- and insulin-like growth factor I-mediated survival of cerebellar granule cells. J Biol Chem 272:9847-9853.

Moore MW, Klein RT, Fariñas I, Sauer H, Armanini N, Phillips H, Reichardt LF, Ryan AM, Carver-Moore K, Rosenthal A (1996) Renal and neuronal abnormalities in mice lacking GDNF. Nature 382:76-79.

Nicholson DW, Ali A, Thornberry NA, Vaillancourt JP, Ding CK, Gallant M, Gareau Y, Griffin PR, Labelle M, Lazebnik YA, Munday NA, Raju SM, Smulson ME, Yamin TT, Yu VL, Miller DK (1995) Identification and inhibition of ICE/CED-3 protease necessary for mammalian apoptosis. Nature 376:37-43.

Nonomura T, Kubo T, Oka T, Shimoke K, Yamada M, Enokido Y, Hatanaka H (1996) Signaling pathways and survival effects of BDNF and NT-3 on cultured cerebellar granule cells. Dev Brain Res 97:42-50.

Oppenheim RW, Houenou LJ, Johnson JE, Lin LF, Li L, Lo A, Newsome AL, Prevette D, Wang S (1995) Developing motor neurons rescued from programmed and axotomy-induced cell death by GDNF. Nature 373:344-346.

Pang L, Sawada T, Decker SJ, Saltiel AR (1995) Inhibition of MAP kinase kinase blocks the differentiation of PC-12 cells induced by nerve growth factor. J Biol Chem 270:13585-13588.

Pichel JG, Shen L, Sheng HZ, Granholm AC, Drago J, Grinberg A, Lee EJ, Huang SP, Saarma M, Hoffer BJ, Sariola H, Westphal H (1996) Defects in enteric innervation and kidney development in mice lacking GDNF. Nature 382:73-76.
Qiu MS, Green SH (1992) PC12 cell neuronal differentiation is associated with prolonged p21ras activity and consequent prolonged ERK activity. Neuron 9:705-717.

Robertson K, Mason I (1995) Expression of ret in the chicken embryo suggests roles in regionalisation of the vagal neural tube and somites and in development of multiple neural crest and placodal lineages. Mech Dev 53:329-344.

Rossi J, Luukko K, Poteryaev D, Laurikainen A, Sun YF, Laakso T, Eerikainen S, Tuominen R, Lakso M, Rauvala H, Arumae U, Pasternack M, Saarma M, Airaksinen MS (1999) Retarded growth and deficits in the enteric and parasympathetic nervous system in mice lacking GFR $\alpha 2$, a functional neurturin receptor. Neuron 22:243-252.

Sanchez MP, Silos-Santiago I, Frisén J, He B, Lira SA, Barbacid M (1996) Renal agenesis and the absence of the enteric neurons in mice lacking GDNF. Nature 382:70-73.

Schuchardt A, D'Agati V, Larsson-Blomberg L, Constantini A, Pachnis V (1994) Defects in the kidney and enteric nervous system of mice lacking the tyrosine kinase receptor ret. Nature 367:380-383.

Shimoke K, Kubo T, Numakawa T, Abiru Y, Enokido Y, Takei N, Ikeuchi T, Hatanaka H (1997) Involvement of phosphatidylinositol-3 kinase in prevention of low $\mathrm{K}^{+}$-induced apoptosis of cerebellar granule neurons. Dev Brain Res 101:197-206.

Soler RM, Egea J, Mintenig GM, Sanz-Rodriguez C, Iglesias M, Comella JX (1998) Calmodulin is involved in membrane depolarizationmediated survival of motoneurons by phosphatidylinositol-3 kinaseand MAPK-independent pathways. J Neurosci 18:1230-1239.

Talanian RV, Quinlan C, Trautz S, Hackett MC, Mankovich JA, Banach D, Ghayur T, Brady KD, Wong WW (1997) Substrate specifities of caspase family proteases. J Biol Chem 272:9677-9682.

Thompson J, Doxakis E, Piñon LGP, Strachan P, Buj-Bello A, Wyatt S, Buchman VL, Davies AM (1998) GRF $\alpha$-4, a new GDNF family receptor. Mol Cell Neurosci 11:117-126.

Treanor JJS, Goodman L, de Sauvage F, Stone DM, Poulsen KT, Beck CD, Gray C, Armanini MP, Pollock RA, Hefti F, Phillips H, Goddard A, Moore MW, Buj-Bello A, Davies AM, Asai N, Takahashi M, Vandlen R, Henderson CE, Rosenthal A (1996) Characterization of a multicomponent receptor for GDNF. Nature 382:80-83.

Trupp M, Rydén M, Jörnvall H, Funakoshi H, Timmusk T, Arenas E, Ibàñez C (1995) Peripheral expression and biological activities of GDNF, a new neurotrophic factor for avian and mammalian peripheral neurons. J Cell Biol 130:137-148.

Trupp M, Arenas E, Fainzilber M, Nilsson AS, Sieber BA, Grigoriou M, Kilkenny C, Salazar-Grueso E, Pachnis V, Arumäe U, Sariola H, Saarma M, Ibañez CF (1996) Functional receptor for GDNF encoded by the c-ret proto-oncogene. Nature 381:785-789.

Trupp M, Raynoschek C, Belluardo N, Ibáñez CF (1998) Multiple GPIanchored receptors control GDNF-dependent and independent activation of the c-Ret receptor tyrosine kinase. Mol Cell Neurosci 11:47-63.

Virdee K, Tolkovsky AM (1996) Inhibition of p42 and p44 mitogenactivated protein kinase activity by PD48059 does not suppress nerve growth factor- induced survival of sympathetic neurones. J Neurochem 67:1801-1805.

Yan Q, Matheson C, Lopez OT (1995) In vivo neurotrophic effects of GDNF on neonatal and adult facial motor neurons. Nature 373:341-344.

Yao RJ, Cooper GM (1995) Requirement for phosphatidylinositol-3 kinase in the prevention of apoptosis by nerve growth factor. Science 267:2003-2006.

Yu T, Scully S, Yu Y, Fox GM, Jing S, Zhou R (1998) Expression of GDNF family receptor components during development: implications in the mechanisms of interaction. J Neurosci 18:4684-4696. 